\begin{tabular}{|c|c|c|c|c|c|c|}
\hline \multirow{4}{*}{ Impact Factor: } & ISRA (India) & $=3.117$ & SIS (USA) & $=0.912$ & ICV (Poland) & $=6.630$ \\
\hline & ISI (Dubai, UAE & $=0.829$ & РИНЦ (Russia & $=0.156$ & PIF (India) & $=1.940$ \\
\hline & GIF (Australia) & $=0.564$ & ESJI (KZ) & $=8.716$ & IBI (India) & $=4.260$ \\
\hline & JIF & $=1.500$ & SJIF (Morocco & $=\mathbf{5 . 6 6 7}$ & OAJI (USA) & $=0.350$ \\
\hline
\end{tabular}

\section{SOI: 1.1/TAS DOI: 10.15863/TAS International Scientific Journal Theoretical \& Applied Science}

p-ISSN: 2308-4944 (print) e-ISSN: 2409-0085 (online)

Year: $2019 \quad$ Issue: 03 Volume: 71

Published: $30.03 .2019 \quad$ http://T-Science.org

SECTION 21. Pedagogy.

Psychology. Innovations in the field of education
QR - Issue
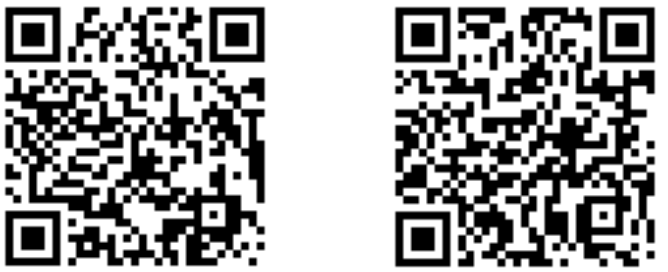

Bunyod Kholiyorov

Head of Department of foreign languages, Independent researcher of

Karshi engineering-economics institute bunyod.xoliyorov@mail.ru +998945263885

http://qmii.uz/ru/inostrannie-yaziki/

Olima Khalilova

Senior teacher of foreign languages department Karshi engineering-economics institute keei.erasmusplus@yahoo.com +998916373849

http://qmii.uz/ru/inostrannie-yaziki/

\title{
METHODS AND MEANS OF PEDAGOGICAL TECHNOLOGIES USED IN FOREIGN LANGUAGE TEACHING
}

Abstract: This article focuses on some theoretical analysis of using pedagogical technologies in foreign language teaching. Moreover, it gives brief explanation on effective methods and their peculiarities.

Key words: pedagogy, forecasting, methods, research, aims, theory, learning process, technologies, educational process, effectiveness, curriculum, visual, quality.

Language: English

Citation: Kholiyorov, B., \& Khalilova, O. (2019). Methods and means of pedagogical technologies used in foreign language teaching. ISJ Theoretical \& Applied Science, 03 (71), 684-686.

Soi: http://s-o-i.org/1.1/TAS-03-71-65 Doi: crossef https://dx.doi.org/10.15863/TAS.2019.03.71.65

\section{Introduction}

Given the accelerated development of society, the evolving needs and capacities of the society, accelerating the flow of diverse information, it is required to create a mechanism for the use of modern pedagogical technology in the teaching of new forms, methods and means of pedagogical prognosis in teaching foreign languages. Today, the use of pedagogical forecasting capacities in research aimed at determining the place and extent of education in different types of educational institutions is required. In particular, the teaching of foreign languages can only result in the development of science, production, culture, economy and all aspects of society. Theories based on pedagogical prognosticity provide the basis for the continuous design of the learning process, the content, the form and the tools of its stages and components, the pre-designation of the impact of educational outcomes on society. Thus, only then can the educational process be reformed on new principles and new ideologies, and reforms in the field of education.

\section{Materials and Methods}

Also, pedagogical technologies in foreign language teaching should develop the methodology and precise mechanisms, methods and means of identifying the educational process and the creation of established theories, educational and methodical complexes on a pilot basis. The mechanism of the learning process identifies achievements and shortcomings of this process, the quality indicators of learning outcomes, the pedagogical theories applied to the educational process, the development of modern teaching technologies or the level of deterrence of education development should be directed. The pedagogical practice test is of particular importance in determining the effectiveness of the results of the research. Depending on the nature of the experiment, it is necessary to create curricula, textbooks and manuals, methodological manuals, didactic developments and deliver the experimental process. If the curriculum is tested, it may be necessary to provide a trained learning process, such as textbooks or manuals, technical aids, visual aids, and teaching 


\begin{tabular}{|c|c|c|c|c|c|c|}
\hline \multirow{4}{*}{ Impact Factor: } & ISRA (India) & $=3.117$ & SIS (USA) & $=0.912$ & ICV (Poland) & $=6.630$ \\
\hline & ISI (Dubai, UAE & $=0.829$ & РИНЦ (Russia) & $=0.156$ & PIF (India) & $=1.940$ \\
\hline & GIF (Australia) & $=0.564$ & ESJI (KZ) & $=8.716$ & IBI (India) & $=4.260$ \\
\hline & JIF & $=1.500$ & SJIF (Morocco & $=5.667$ & OAJI (USA) & $=0.350$ \\
\hline
\end{tabular}

aids. It focuses not only on the methodology used by the teacher, but also on the effectiveness of the teaching materials provided within the curriculum. In particular, the results from the theories and the experimental classes involved in the experimental trial require statistical analysis. Attracting the leading scientific and pedagogical teams and leading experts will require the examination and testing of their results. The expertise of the results and results of the large-scale experiments shall be carried out in accordance with the requirements of the previously approved statutes of the scientific and pedagogical community.

Today, the pedagogical forecasting of our society shows itself as an important branch of pedagogical science with its clear goals and objectives, object and object, logical bases of research, development laws, its basic methodology, has it? Pedagogical prognostics is a priority area of science, aimed at improving the quality of training of the continuous education system, which serves the development of the state and society, on the basis of new models of education and the emergence of new pedagogical theories.

The pedagogical prognosis chooses educational technologies, taking into account the age characteristics of the student and the dynamics of development. Within the framework of certain selected educational technologies, students offer students the ways, shapes and tools they offer to get different levels of understanding and knowledge. Theoretical basis of a particular pedagogical technology should include pedagogical prognostics, the organization of the educational process, aimed at ensuring the active functioning of the pupil and the teacher, the development of his / her own freedom of thought and creativity.

Any pedagogical technology that is applied to the learning process, whether it is through the content of its components or the content, or whether it is through a curriculum or a textbook or a teacher activity, it is necessary to achieve rapid development. At the same time, pedagogical technologies, first of all, allow each student to communicate freely with other students, teaching materials and teacher (pedagogue), to exchange ideas. Modern pedagogical technologies should reflect the pedagogical practice as a form of knowledge that defines a set of laws, nature and society phenomena, personality culture and morals, and certain science bases for the student or student. It is desirable to rely on the theoretically sound, comprehensively tested and accurate code of conduct in this area. The main focus of pedagogical technology is to develop positive attitudes and qualities on the basis of their needs, interests, talents and abilities. At the same time, the content of education is an environment for the formation and development of a person. Therefore, the content of the training should be based on humanitarian ideas and standards.

Pedagogical technology on the basis of humanization and democratization of pedagogical relationships is radically opposed to single-managing technology and creates favorable conditions for personal development and creativity through cooperation in the pedagogical process, caregivers, respect for students' personalities. In subjects of traditional education, teacher (pedagogue) is considered to be the subject of educational content, as students-students are considered to be objects of pedagogical process, in the collaboration pedagogy student-student is the subject of self-discipline . That is why cooperative pedagogy solves the educational objectives of the two subjects of a single educational process.

This pedagogical technology plays an important role in the center of the education system, aimed at the formation and development of the human personality. The extent to which this idea is realized is the main outcome of the educational process, based on the assessment of the quality of pedagogical team work. The most important factor determining the main outcome of the educational process in humanization and democratization of pedagogical relations is the attitude towards the individual.

The difference between human beings and other creatures is that it sets itself a certain goal and moves towards it. A person's goal is to overcome certain natural and artificial obstacles in his work. In order to overcome these barriers, he uses a number of measures and measures. A set of measures and measures to overcome a certain barrier to achieving this goal is called the method.

Human achievement has to overcome several, sometimes dozens, obstacles. Appropriate methods are used to overcome these barriers in a particular system. The methods used to achieve the goal are called the style of the system.

Whenever a method is used in a particular manner, each movement status is subject to specific target indicators. In addition, human beings act as a principle for a number of legitimate goals.

\section{Conclusion}

The method of teaching is a pedagogical event that regulates the interaction between the teacher (pedagogue) and the student-student education. Teaching methods are a major part of the learning process. It is impossible to carry out pedagogical activities without the appropriate methods.

Methods are divided into visual, practical, and practical, depending on the nature of the transmit and receive information. When designing educational content, students are encouraged to use the following methods, such as: Illustrative, Illustrative, Reproductive, Problematic, Private Search or Intuitive and Semi-Research Methods. 


\begin{tabular}{|c|c|c|c|c|c|c|}
\hline \multirow{4}{*}{ Impact Factor: } & ISRA (India) & $=3.117$ & SIS (USA) & $=0.912$ & ICV (Poland) & $=6.630$ \\
\hline & ISI (Dubai, UAE & $=0.829$ & РИНЦ (Russia & $=0.156$ & PIF (India) & $=1.940$ \\
\hline & GIF (Australia) & $=0.564$ & ESJI (KZ) & $=8.716$ & IBI (India) & $=4.260$ \\
\hline & JIF & $=1.500$ & SJIF (Morocco & $=5.667$ & OAJI (USA) & $=0.350$ \\
\hline
\end{tabular}

Problem-solving methods are used in a problematic learning process. In using these methods, the teacher (teacher) first creates a problematic situation, issues questions, proposes issues, assignments, arranges a discussion on solving a problem situation, and confirms their conclusions. Pupils-students present their ideas on how to solve a problem based on their previous knowledge and experience and prioritize their knowledge, choosing the most reasonable option for solving the problem situation. This method not only increases students' interest in knowledge, but also develops their thinking skills.
Once there are clear means of achieving pedagogical goals, the teacher can be convinced that his work is effective and that his chosen methods are appropriate or vice versa. This is exactly what pedagogical technicians used to do when studying the teaching method.

The pedagogist receives an order from the public. Even the objectives set out in the curriculum are limited to a few explanations. Here, you can build a specific culmination of objectives: from the general requirements of society - the responsibilities of the education system, including the particular subject matter, the subject matter, its subject departments.

\section{References:}

1. Goziev, Y. Y. (2002). General Psychology. (p.19). Tashkent.

2. Kamoliddinova, D. (2013). AnSU, Faculty of Pedagogy Development and introduction of innovative methods of education. (p.90-93). Andijan.

3. Yuldoshev, J. (1999). New pedagogical technology: its trends, problems, solutions. Public Education, Issue 4, 72.

4. Mahmudov, M. (2003). Design of educational outcomes. Pedagogic Skills, Issue 1, 10.

5. Dulepova, Y. V. (2013). Formation of general cultural competence of the modern specialist graduate of the technical university at the classes of foreign languages. Proceedings of Oryol State University. Series: Humanities and Social Studies, \# 5, 235-238.

6. Frolova, N. A., \& Aleshchanova, I. V. (2013). Professionally-oriented approach in teaching of foreign languages in the technical university.
Bulletin of Volgograd State Technical University, Vol. 14, \# 16 (119), 88-90.

7. Latypov, N. R., \& Sabirova, D. R. (2013). Competence-based Approach to Aeronautical Engineering Education: Language Aspect. Interactive Collaborative Learning (ICL), 2013 International Conference. Digital Object Identifier: 10.1109/ICL.2013.6644664, KSTU. (pp.617-618). Kazan.

8. Slesarenko, I. V. (2007). Goal-setting in teaching a foreign language in the technical university: interdisciplinary approach. Bulletin of Tomsk State University, \# 296, 59-61.

9. Rayan, A. P. (2008:1). Assessing Communication Apprehension, Education Express. (p.2). The New Indian Express, 11 Aug.

10. Tyagi, R. A. (2006). Effective Methods of Teaching English. New Delhi: Alpha Publications. 